\title{
The impact of alternative assets on the performance of Brazilian private pension funds*
}

\author{
Francis Amim Flores ${ }^{1}$ \\ (D) https://orcid.org/0000-0002-3741-9820 \\ Email: francis.flores@hotmail.com \\ Carlos Heitor Campani ${ }^{1,2}$ \\ (D) https://orcid.org/0000-0003-1896-7837 \\ Email: carlos.heitor@coppead.ufrj.br \\ Raphael Moses Roquete ${ }^{3}$ \\ (D) https://orcid.org/0000-0001-5554-0379 \\ Email: raphael@facc.ufrj.br
}

\author{
${ }^{1}$ Universidade Federal do Rio de Janeiro, Instituto Coppead de Administração, Departamento de Finanças e Controle Gerencial, Rio de Janeiro, \\ RJ, Brazil \\ ${ }^{2}$ Edhec-Risk Intitute, Nice, France \\ ${ }^{3}$ Universidade Federal do Rio de Janeiro, Faculdade de Administração e Ciências Contábeis, Departamento de Ciências Contábeis, Rio de \\ Janeiro, RJ, Brazil
}

Received on 04.08.2020 - Desk acceptance on 04.29.2020 - $2^{\text {nd }}$ version approved on 08.05.2020

Editor-in-Chief: Fábio Frezatti

Associate Editor: Fernanda Finotti Cordeiro

\section{ABSTRACT}

This article assesses the impact of alternative assets on the performance of Brazilian private pension funds. Few studies touch on this topic in Brazil and most only investigate the addition of alternative assets and their impact on the performance. The market of open private pension funds in Brazil has been growing rapidly in recent years and gaining much relevance, especially after the announcement of the reformulation of the Brazilian pension system. In 2018, the Free Benefit Generating Plan (PGBL) and the Free Benefit Generating Life (VGBL) represented more than $94 \%$ of total assets in their sector. The Brazilian specially constituted investment funds (FIEs) of PGBL and VGBL private pension plans are characterized by their dependence on fixed income assets. Brazil currently faces an unprecedent low interest rate scenario - which, following a worldwide panorama, seems to be set for a long time - and pension fund managers must search for alternative investments that aggregate both risk premia and diversification. The results of this study may support managers in this little-discussed matter. We compare the performance of FIEs without additional alternative assets versus the portfolio with alternative assets, adding a hedge fund index, an equity mutual funds index, a commodity index, an electric power index, a public utilities index, a gold index, and a real estate index. Several performance measures were used, considering Brazilian regulations and a rebalancing strategy. Our results showed that almost all alternative assets used in this study improved the performance of the Brazilian FIEs of PGBL and VGBL private pension plans, especially the public utilities index and the hedge fund index. Some even improved the portfolio tail risk.

Keywords: private pension, alternative assets, performance measurement.

Correspondence address

Carlos Heitor Campani

Universidade Federal do Rio de Janeiro, Instituto Coppead de Administração

Rua Pascoal Lemme, 355 - CEP 21941-616

Cidade Universitária - Rio de Janeiro - RJ - Brasil

\footnotetext{
* Carlos Heitor Campani is grateful to the Catedra Brasilprev em Previdência, to the National Council for Scientific and Technological Development (CNPq), to the Rio de Janeiro State Foundation to Support Research (Faperj), and to the Escola Nacional de Seguros (ENS) for their financial support to conduct this study.
} 


\section{INTRODUCTION}

The inclusion of alternative assets into the portfolios of pension funds is growing worldwide and the number of studies on this topic have also grown. Brazilian regulations have been changed; however, the diversification through alternative investments does not follow the global rhythm. Moreover, studies on alternative assets and their impacts on pension funds in Brazil are incipient, with most only investigating the addition of alternative assets and their impact on the performance of closed private pension funds (e.g., commodities [Costa \& Piacenti, 2008]; derivatives [Costa et al., 2014]; private equity [Lopes \& Furtado, 2006]; international investments [Silva et al., 2009]; hedge funds [Leal \& Mendes, 2009]). The results are consistent: all concluded that these assets improved the performance of closed pension funds. Given the deficit in the literature on open private pension funds in Brazil, more specifically, the Brazilian specially constituted investment funds (FIEs) of the Free Benefit Generating Plan (PGBL) and the Free Benefit Generating Life (VGBL) private pension plans, we question: can the addition of alternative assets improve the performance of open private pension funds?

The Brazilian government has been trying to reformulate the pension system to ease the pressure on public accounts; private pension funds have thus gained prominence. According to the Brazilian National Federation of Private Pension and Life (FenaPrevi), this market has been growing at $20 \%$ p.y over the last ten years. The VGBL and PGBL plans are the most popular private pension plans in Brazil, accounting for $94.70 \%$ of the sector and $99.13 \%$ of issued plans in July 2018 (FenaPrevi, 2018). These plans are life insurances with survival coverage. For practical matters, the single difference between them is the way how income tax is levied. Such plans are also structured as specially constituted investment funds (FIEs) and marketed as any other financial instrument. For more details, see Campani and Costa (2016).

Since this is an increasingly competitive market, performance must be a central point in this debate; managers of these funds must demonstrate a good performance in comparison to other products to attract and maintain new participants.

These funds are historically dependent on fixed income assets and their asset allocation has always been very constrained by law. Fortunately, in 2015, the National Monetary Council (CMN) launched a new regulation, empowering FIEs with more diversification options. However, due to the historical attractiveness of the Brazilian standard rate (Selic) this change was not enough to break the dependence of FIEs on fixed income assets.

The economical panorama changed drastically in 2019. The fixed income market is facing one of the lowest interest rate trajectories in history, leading participants to gradually migrate to other options in search for higher returns. According to FenaPrevi, $11.6 \%$ of private pension funds' assets are allocated in hedge funds. This percentage was $10.2 \%$ in $2018 ; 8.1 \%$ in 2017 ; and $5.7 \%$ in 2016 .

These results show that the addition of a small portion of an alternative asset may improve the performance of FIEs, and when added in greater proportion, this improvement becomes more relevant. We considered several alternative assets that a fund manager might invest in: a hedge fund index, an equity mutual funds index, a commodity index, an electric power index, a public utilities index, a gold index, and a real estate index. Our sample ranges from January 2009 until December 2018.

\section{LITERATURE REVIEW}

Since the subprime crisis in 2008, financial markets have witnessed historically low interest rates, challenging investors - especially pension fund managers who rely on yield-related promises. This scenario led investors to look for higher returns outside the traditional asset classes (Kräussl et al., 2017), meaning the pursue for better returns may bring higher risks. Becker and Ivashina (2015) show that insurance firms tend to buy bonds with higher systematic risk to achieve higher yields and this behavior depends on the business cycle, being much more prominent during economic expansions. However, this asset class becomes very limited when a financial crisis dramatically affects the interest rate. Thus, alternative assets such as real estate, commodities, hedge funds, mutual funds, and funds of funds have become crucial for institutional investors.

Platanakis et al. (2018) explain that investments in alternative assets have increased in recent decades and should continue to do so. A global pension fund study by Willis Towers Watson (2018) shows that, from 1997 to 2017, alternative assets allocations in portfolios of pension schemes in the U.S., Australia, the U.K., Canada, 
Netherlands, Switzerland, and Japan have increased from $4 \%$ to $25 \%$, highlighting an increase of $10 \%$ in the U.S. and $9 \%$ in the U.K. Interestingly, this trend is not an aspect only of developed countries since an OECD (2018) study states that some African countries invested more than $40 \%$ of their assets in alternative investments. Moreover, a survey from Willis Towers Watson (2017) states that pension fund assets managed by the top 100 asset managers increased almost $9 \%$ from 2016, reaching $\$ 1.6$ trillion, which is equivalent to $51 \%$ of their total assets under management. This scenario reinforces the importance of studies on alternative investments and the benefits brought by this strategy.

Outside of Brazil, the literature has extensively studied whether alternative assets provide positive risk-adjusted returns to a traditional asset portfolio, including pension funds' portfolios. For instance, real estate (Andonov et al., 2013), commodities (Bessler et al., 2015), hedge funds (Bali et al., 2013), private equity (Harris et al., 2014; Nielsen, 2011). All these studies concluded that alternative assets are beneficial for the risk-return profile of portfolios.

Nonetheless, the decision to include alternative assets into portfolios depends not only on the risk-return benefits, but on the diversification benefits granted by them. Many studies have investigated diversification benefits of adding alternative assets into traditional and pension portfolios (e.g., hedge funds) (Amin \& Kat, 2003a; Amin \& Kat, 2003b; Favre and Galeano, 2002; Gregoriou \& Rouah, 2002); commodities (Belousova \& Dorfleitner, 2012; Daskalaki et al., 2017); international investments (Davis, 2005); infrastructure (Newell \& Peng, 2008). Similar to studies on the risk-return effect, these studies concluded that alternative assets are advantageous to the portfolios in terms of diversification.

The study by Jackwerth and Slavutskaya (2016) is worth mentioning since it compared the addition of many alternative assets into pension funds' portfolios, such as hedge funds, real estate, commodities, foreign equities, mutual funds, funds of funds, and some counter cyclical and non-cyclical assets. Their main objective was to analyze the total benefit derived from diversification, addition of positive skewness, and the elimination of left tails returns. The results showed that adding hedge funds portfolios produced significantly greater total benefit than any other alternative asset.

In Brazil, the National Monetary Council (CMN) empowered the open private pension funds with more diversification options through CMN Resolution n. 4,444. Before it, only $49 \%$ of total assets under management could be allocated in variable income; now, $70 \%$ can be allocated and, within this proportion, $10 \%$ can be distributed into assets with currency variation, for example. Moreover, new kinds of assets were included, such as real estate funds (FII), limited to $20 \%$ of the portfolio. Another highlight was the characterization of "Qualified Investors", which are defined by CVM Instruction n. 554 as investors with financial investments over one million BRL (Brazilian currency). This kind of investor can invest $100 \%$ in variable income, $40 \%$ in real estate, and $10 \%$ in assets with currency variation.

According to the statistical report by Superintendência de Seguros Privados (Susep, 2018), the participation of the insurance market - including insurance, open private pension and capitalization markets - on the Brazilian GDP represented a strong evolution, increasing from $2.59 \%$ in 2003 to $3.77 \%$ in 2017 . This is quite significant since the Brazilian GDP continued to grow for most of the period. The open private pension market accounted for $1.85 \%$ of the Brazilian GDP, and from 2003 to 2017, its revenues more than tripled in real terms (Susep, 2018).

This scenario indicates that alternative assets can become a considerable portion of pension funds in Brazil. However, the historical high interest rate level in the country may have led investors to prefer fixed income funds, which may have created a barrier for alternative investments. Susep (2015) conducted a study that revealed that PGBL and VGBL funds allocate $98 \%$ of their net worth in fixed income and, within this proportion, $75 \%$ is invested in public bonds, $15 \%$ in private bonds and $10 \%$ in fixed income funds. The cumulative interest rate as measured by Selic, a standard government benchmark for the Brazilian risk-free rate, reached $816 \%$ in nominal Brazilian currency terms from January, 2001 until November, 2018. In the same period, the Ibovespa Index (main stock index in Brazil) reached $476 \%$ in cumulative return and the cumulative inflation was 203\% (as given by the Brazilian National Consumer Price Index - IPCA). These rates were calculated using the information available in the Brazilian Central Bank and B3 website.

An analysis of the data provided by Susep (SES website) revealed that out of 176 companies (Insurance, Reinsurance, Capitalization, and Open Private Pension Entities), $110(63 \%)$ possess at least $95 \%$ of total assets under management allocated in fixed incomes, 92 (52\%) do not invest in variable income, $122(69 \%)$ do not invest in real estate and $131(74 \%)$ invest less than $2 \%$ of total AUM in "Others". These estimates show that alternative investments are not a common practice in Brazil, reinforcing the high dependence on fixed income 
assets. Nonetheless, this scenario is changing, the same movement that took place outside Brazil after the subprime crisis is happening now. The Brazilian Central Bank reduced the Selic to 5\% p.y. in 2019, bringing it to its lowest level in history. For comparison, this rate was almost three times bigger in 2015 (14.5\%); this interest rate is expected to remain low in the future, as the 10 -year Brazilian government bond has a $6.853 \%$ yield.

Conti (2016) explains that most open private pension funds are managed by commercial banks, being offered to customers as a financial investment like any other. Campani and Soares (2019) state that in December 2017 five companies linked to large commercial banks (Bradesco, BrasilPrev, Caixa Econômica Federal, Itaú, and Santander) controlled 91\% of the total PGBL and
VGBL net worth. Therefore, these investments are not totally seen as pensions strategies, but are viewed as financial investments that compete with other products of the bank. Consequently, managers of these funds are induced to advertise these plans as a profitable option and, to attract new participants (and keep them), these funds must present satisfactory performance when compared to the other products. If the performance of the open pension fund is not competitive in the short horizon, participants will migrate to other investment options while the true goal should be the long-term perspective. Regulation should monitor this matter, and this study seeks to assess the importance of alternative investments on these funds' performances, shedding important light on this debate.

\section{DATA AND METHODOLOGY}

\subsection{Data and Sampling}

The main objective of this work is to investigate the overall attractiveness of adding alternative assets to the Brazilian FIEs of PGBL and VGBL. To do so, the monthly returns of 2,331 funds, including the ones that ceased to exist, were downloaded from the Economatica ${ }^{\circledR}$ database. Campani and Brito (2018) categorized these funds in three different modalities depending on the institution, usually as follows: conservative funds (allowed to invest only in fixed income instruments), moderate funds (allowed to invest $15-30 \%$ in variable income) and aggressive funds (40-49\% in variable income) - interestingly, some very recent funds are already extending this limit to $70 \%$ due to the new regulation (CMN n. 4,444).

Our calculations used only aggressive funds since they are the ones that allow investments in greater proportion of different types of assets, reducing our sample to 1,329 funds (399 inactive and 930 active). The time frame selected covered 120 months (from January 2009 to December 2018), which encompasses different market states and provides the longest period of available data. During this period, the Brazilian economy experienced a recession in the first quarter of 2009, an enormous GDP growth from March 2009 to the beginning of 2014, the worst recession of Brazilian history (2014-2016) and a slow recovery period (20172018). Moreover, only funds with at least ten years of existence and available data were chosen, leaving us with 128 active and aggressive funds.

Aware of sample selection and survivorship biases, we tested if there are statistically significant differences between three groups: all FIEs of PGBL and VGBL, all aggressive funds, and our chosen sample (we note that all the active and inactive funds were considered). The first step was checking if a parametric test would be the best option; a Levene Test was conducted to assess the hypothesis of equality of variances. The null hypothesis was rejected at any reasonable test significance $(\mathrm{F}(2,357)=29.39, \mathrm{p}$-value $=0.00)$, concluding that a non-parametric test would be a better alternative. The Kruskal Wallis Test was thus performed and we concluded that there is no significant difference between the groups at any reasonable significance level (Chi square $=0.11004, \mathrm{df}=2, \mathrm{p}$-value $=0.9465)$. This result indicates that our sample is representative for the analyses. Table 1 presents the descriptive statistics of the groups. 
Table 1

Descriptive statistics of the equally weighted portfolio of all FIEs of PGBL and VGBL portfolios, all aggressive funds and the aggressive sample from January 2009 to December 2018

\begin{tabular}{lccc}
\hline & Aggressive sample portfolio & All aggressive funds' portfolios & All FIEs of PGBL and VGBL portfolio \\
\hline Jarque-Bera (p-value) & 0.9430 & 0.8424 & 0.7890 \\
\hline$\mu$ & 0.0077 & 0.0077 & 0.0075 \\
\hline$\sigma$ & 0.0205 & 0.0136 & 0.0093 \\
\hline Skewness & 0.0713 & 0.1324 & -0.0913 \\
\hline Kurtosis & -0.0112 & 0.0676 & 0.3120 \\
\hline Minimum monthly return & -0.0424 & -0.0287 & -0.0188 \\
\hline Maximum monthly return & 0.0652 & 0.0429 & 0.0331 \\
\hline
\end{tabular}

Source: Elaborated by the authors.

The alternative assets selected were indexes that we believe to be representative of investable portfolios. We used ANBIMA's hedge funds index (IHFA), Brazilian Central Bank's equity mutual funds index (IFA), B3's commodity index (ICB), B3's electric power index (IEEX), B3's public utilities index (UTIL), B3's gold index (OZ1D), and a proxy of real estate investments, B3's real estate index (IMOB) (a representative index for the Brazilian real estate sector). We did not use the B3'S REIT index
(IFIX) due to its small sampling size. All data are available in monthly returns from January 2009 to December 2018. The choice of most of the assets used (IFA, IHFA, IMOB, ICB, and gold) was inspired on the work of Jackwerth and Slavutskaya (2016). The others, IEEX and UTIL, were chosen out of curiosity because of the market they represent, i.e., basic utilities have great room for growth in developing countries. Table 2 shows the descriptive statistics of all alternative assets.

Table 2

Descriptive statistics of all alternative assets from January 2009 to December 2018

\begin{tabular}{lcccccccc}
\hline & UTIL & IMOB & IEEX & IFA & IHFA & Gold & ICB \\
\hline$\mu$ & 0.0130 & 0.0120 & 0.0112 & 0.0106 & 0.0099 & 0.0088 & 0.0062 \\
\hline$\sigma$ & 0.0564 & 0.0928 & 0.0541 & 0.0377 & 0.0087 & 0.0503 & 0.0329 \\
\hline Skewness & 0.1518 & 1.9442 & 0.2251 & 0.0974 & 0.0456 & -0.0434 & 0.3910 \\
\hline Kurtosis & 1.4498 & 8.2945 & 1.1172 & 0.6938 & 1.7585 & 0.0433 & -0.1354 \\
\hline Minimum monthly return & -0.1267 & -0.1413 & -0.1272 & -0.0855 & -0.0220 & -0.1288 & -0.0611 \\
\hline Maximum monthly return & 0.2235 & 0.5395 & 0.1953 & 0.1299 & 0.0373 & 0.1503 & 0.0930 \\
\hline
\end{tabular}

Source: Elaborated by the authors.

Finally, we adjust the returns of all funds and alternative assets to the IBGE's inflation index (IPCA), which means that everything in this work was calculated in real terms.

\subsection{Methodology}

We must follow the regulation to add alternative assets to the portfolio of FIEs. The lower bound of the regulation sets a limit of $10 \%$ for any "Investment abroad", which is the investment of greater risk allowed in a FIE portfolio. Some funds composing the IHFA (hedge fund index) contain the suffix "Investment abroad", thus being able to represent until $10 \%$ of the FIE portfolio. We thus restrict the addition of our alternative assets to this limit (10\%).
Campani and Brito (2018) show that aggressive FIEs usually invest only $80 \%$ of the total variable income limit, so they do not take a high risk of reaching this limit and get out of the regulation. Therefore, we set an upper limit of $8 \%$ (instead of $10 \%$ ).

Following, 5\% was chosen as the middle point of the limit (10\%) to begin our simulations. We start by selling $5 \%$ of the current fund portfolio (in proportion) and adding $5 \%$ of an alternative asset. In the end, we vary the weight of these assets within the limit range (1\% to $8 \%$ ) and analyze the results above and below the middle point.

The rebalancing strategy is crucial so that we can ensure that our study does not inflict the regulation. For this reason, our rebalancing strategy was inspired by 
Gutierrez, Pagnoncelli, Valladão and Cifuentes (2019), who explain that the choice of the rebalancing period is somewhat arbitrary, since longer periods may affect the effectiveness of the asset allocation, whereas very short periods may undermine the passive approach to longterm objectives. Moreover, transaction costs are relevant in this strategy since taking too long to rebalance can result in lower trading volumes and transaction costs. However, the share of alternative assets may exceed the limit imposed by the regulation. On the other hand, frequent rebalancing can lead to higher transaction costs. Therefore, we chose to work with semi-annual rebalancing.
Several measures are used to estimate the total benefit of adding alternative assets to FIEs of PGBL and VGBL. Overall, performance measurements can be split into three main groups: mean-variance ratios, factor models and utility-based models. From the mean-variance group, we use the Sharpe ratio, the historical VaR (as a tail risk measure) and the Upside Potential ratio (UPR), introduced by Sortino, van der Meer, and Plantinga (1999). Since the Brazilian risk-free rate is historically high, the excess return can be negative sometimes, causing the Sharpe ratio to lose its interpretation. To overcome this issue we apply the modified Sharpe ratio presented by Israelsen (2005):

$$
S R_{i}=\frac{\left(\overline{R_{i, t}}-\overline{R_{f, t}}\right)}{\sigma_{i} \frac{R_{i, t}-R_{f, t}}{a b\left(R_{i, t}-R_{f, t}\right)}}
$$

where $S R_{i}$ represents the Sharpe ratio for fund, $i, \overline{R_{i, t}}$ is the average monthly return of fund $i, \overline{R_{f, t}}$ is the average monthly Brazilian risk-free rate (CDI rate), $\sigma_{i}$ is the standard deviation of the historical values of the excess returns, and $a b s$ is the absolute value of the excess return. For this study, the CDI rate (Brazilian Interbank Deposit Rate) will be used as the risk-free asset instead of Selic (rate for government securities). Both behave similarly and most funds in Brazil use this rate as the risk-free benchmark in their monthly performance reports.
Although these ratios are widely used in the funds' performance literature, they are subject to criticism. For robustness purposes we also use a factor model risk measure and propose an eight-factor model to estimate alphas. Since we are adding different classes of assets, the portfolio will be subject to different sources of risks; to explain most of these risks and determine the excess returns (alphas), our model is based in Campani and Soares' (2019) six factor model for aggressive FIEs, adding the illiquidity (Illiquid-minus-Liquid - IML) factor and ANBIMA's debenture index (IDA):

$$
\begin{gathered}
R_{i, t}-R_{f, t}=\alpha_{i}+\beta_{i} \times\left(R_{M, t}-R_{f, t}\right)+h_{i} \times\left(H M L_{t}\right)+s_{i} \times\left(S M B_{t}\right)+w_{i} \times\left(W M L_{t}\right) \\
+q_{i} \times(I M L)+g_{i} \times\left(I M A B_{t}-R_{f, t}\right)+f_{i} \times\left(I R F M_{t}-R_{f, t}\right)+c_{i} \times\left(I D A_{t}-R_{f, t}\right)+e_{i, t}
\end{gathered}
$$

where $R_{i, t}$ is the fund $i$ return at time $t, R_{f, t}$ is the Brazilian risk-free rate (CDI rate) at time t, $\alpha_{i}$ is the fund $i$ alpha, $R_{M, t}$ is the market benchmark at time t, $H M L_{t}$ is the standard High-minus-Low factor at time t, $S M B_{t}$ is the standard Small-minus-Big factor at time t, $W M L_{t}$ is the standard Winners-minus-Losers factor at time t, $I M A B$ is the ANBIMA's index for government bonds indexed by the IPCA at time $t, I R F M_{t}$ is the ANBIMA's index for government bonds with pre-fixed rates at time $\mathrm{t}$, and $e_{i}$ is the error term at time t. The IBrX100 index is used as the market benchmark: Campani and Brito (2018) justify this choice based on previous studies showing that this index has superior performance when compared to the Ibovespa index due to its better diversification. The other risk factors (HML, SMB, WML, and IML) were retrieved from the NEFIN Center website.

Another issue is that it is questionable if the fund that delivered a high alpha in the past will continue to do it in the future. Goetzmann et al. (2007) demonstrate that alpha and ratios can be manipulated, increasing a fund's performance measure without adding value to the funds' investors. They thus propose a non-parametric utilitybased model that cannot be gamed by active trading called Manipulation-Proof Performance Measure (MPPM), being very robust to excessive use of dynamic trading strategies and manipulation of return distributions.

To better measure the benefits of alternative assets, we follow Goetzmann et al. (2007) and use the MPPM: 


$$
M P P M=\frac{1}{(1-\rho) \Delta t} \ln \left(\frac{1}{T} \sum_{t=1}^{T}\left[\left(1+R_{i, t}\right) /\left(1+R_{f, t}\right)\right]^{1-\rho}\right)
$$

where the MPPM is an annualized estimate of the portfolio's premium after adjusting for risk. That is, the portfolio has the same score as a risk-free asset whose compounded return exceeds the interest rate by the MPPM value. To facilitate the reader's comprehension, consider that the monthly risk-free rate is $1 \%(12.7 \%$ annually). If the MPPM is $5 \%$ then the fund is equivalent to a risk-free asset returning $17.7 \%$ annually. Here, $\Delta t$ is the length of time between observations (in years), $T$ is the total number of observations, $R_{i, t}$ is the fund's $i$ return at time $t$, and $R_{f, t}$ is the CDI rate at time t. The coefficient $\rho$ is explained by Goetzmann et al. (2007) as a risk parameter that should be selected to make the benchmark optimal for an uninformed participant (i.e., who has no knowledge about financial securities):

$$
\rho=\frac{\ln \left(1+\overline{R_{M, t}}\right)-\ln \left(1+\overline{R_{f, t}}\right)}{\operatorname{Var}\left[\ln \left(1+R_{M, t}\right)\right]}
$$

where $\overline{R_{M, t}}$ is the average monthly return of the benchmark (IBrX100) and $\overline{R_{f, t}}$ is the average monthly rate of the risk-free asset (CDI). To calculate this parameter, we take the averages from January 2001 to December 2018nd substitute their values into the Eq. (4) to get our $0.85 \rho$ estimation. Some Brazilian authors have used a relative risk aversion parameter equal to 3, such as Ornelas et al. (2008) and Catalão and Yoshino (2004); however, their studies were elaborated more than ten years ago and this parameter may change depending on the state of the market, leading to a very different value. So, to leave no uncertainty in this regard, we also test for different $\rho$ values, varying from 0.85 to 3 .

Finally, to check if alternative assets can really bring benefits and if the MPPM is capable of measuring these benefits, we answer three questions. Firstly, we question if alternative assets can bring any benefit to the FIEs. To answer this question we measure the original portfolio MPPM (without alternative assets) of each fund in our sample and then recalculate the returns and the MPPM of the new portfolio (containing one kind of alternative asset), selling $5 \%$ (in proportion) of the original portfolio and buying $5 \%$ of an alternative asset. Following, we calculate the $\triangle \mathrm{MPPM}$ as the MPPM of the new portfolio minus the MPPM of the original portfolio. This will create a cross-sectional list of $\triangle$ MPPM values, facilitating further comparisons. We repeat this procedure for each method: the modified Sharpe ratio, UPR ratio, historical VaR and the excess return (alpha). In the end, we use a paired t-test for the means of each method to check if the difference $(\Delta)$ is significantly different from zero.

Our second question investigates which alternative asset provides the greatest benefit to the fund. To answer it, we take the alternative asset that provided the greatest cross-sectional mean of total benefit (MPPM) and compare its performance to the others. As in the first question, we calculate the $\triangle \mathrm{MPPM}$ as the MPPM of the portfolio with the best alternative asset minus the MPPM of the portfolio with another alternative asset and repeat the procedure for each performance method. We then use a paired t-test for the difference $(\Delta)$.

Our last question concerns the failures of alpha and its ability to estimate the persistence of funds' performance, since it is exposed to several estimation problems, such as omitted variables and large standard errors (related to low $\mathrm{R}^{2}$ ). Thus, the idea here is to check if the MPPM - which is less susceptible to these drawbacks - will have a better persistence over time.

To test it, we use rolling windows of 24,48 and 60 months with step sizes of 12, 24 and 30 months respectively. We describe the steps for the 24-month window as follows: the window is divided into two subperiods of 12 months each. For the first half (1-12 months) we calculate the $\mathrm{MPPM}_{1 \mathrm{i}}$, where $i$ represents the fund $i$, and for the second half (13-24 months) we calculate the $\mathrm{MPPM}_{2 \mathrm{i}}$. The next window starts at the $13^{\text {th }}$ month and we execute the same procedure repeatedly until reaching the 120 months of our sample. Thereafter, we estimate $\triangle \mathrm{MPPM}_{1 \mathrm{i}}$ and $\triangle \mathrm{MPPM}_{2 \mathrm{i}}$, as the $\mathrm{MPPM}_{1 \mathrm{i}}\left(\right.$ or $\left._{\mathrm{MPPM}} \mathrm{M}_{2 \mathrm{i}}\right)$ of the new portfolio minus the $\mathrm{MPPM}_{1 \mathrm{i}}\left(\right.$ or $\left._{\mathrm{MPPM}} \mathrm{MP}_{2 \mathrm{i}}\right)$ of the original portfolio. This will result in cross-sectional $\triangle \mathrm{MPPM}_{1 \mathrm{i}}$ (and $\triangle \mathrm{MPPM}_{2 \mathrm{i}}$ ) values that we can regress the $\triangle \mathrm{MPPM}_{2 \mathrm{i}}$ on the $\triangle \mathrm{MPPM}_{1 \mathrm{i}:}$

$$
\triangle M P P M_{2 i}=a_{M P P M}+b_{M P P M} \times \triangle M P P M_{1 i}+e_{i}
$$

where $a_{M P P M}$ and $b_{M P P M}$ are the parameters to be estimated and $e_{i}$ is the error term. So, we stack all $\triangle \mathrm{MPPM}_{1 \mathrm{i}}\left(\mathrm{MPPM}_{2 \mathrm{i}}\right)$ values and regress them to find a unique $b_{M P P M}$, which must be positive and statistically significant to ensure that there is performance persistence over time. Finally, we repeat the same process for the alpha estimated by the eight-factor model proposed on this study:

$$
\Delta \alpha_{2 i}=a_{\alpha}+b_{\alpha} \times \Delta \alpha_{1 i}+k_{i}
$$

here, the $\Delta \alpha_{2 i}$ and $\Delta \alpha_{1 i}$ are the $\alpha_{1 i}\left(\alpha_{2 i}\right)$ of the new portfolio minus the $\alpha_{1 i}\left(\alpha_{2 i}\right)$ of the original portfolio, $a_{\alpha}$ and $b_{\alpha}$ are the parameters to be estimated and $k_{i}$ is the error term. 
Challenging our study and investigating whether it is based on the set of assumptions defined above is fundamental, so robustness tests must be performed:

1. Use different coefficients of risk-aversion instead of using only $\rho=0.85$. We replicate the main results using $\rho=2$ and $\rho=3$.

2. Apply different weights to the addition of alternative assets, varying from $1 \%$ to $8 \%$.

3. Instead of using the eight-factor model, we reduce it to five factors, taking out the IML factor and creating the new risk-free factor. Before describing the development of a new factor, it is important to notice that there is no market index that represents the Brazilian fixed income market (i.e., that includes the private market).
Having said that, the new factor was calculated as described: analyzing the Economatica ${ }^{\circledR}$ database, our sample of FIEs of PGBL/VGBL allocate 15.5 times more treasurbonds than debentures. Thus, the new risk-free factor is determined considering this ratio and using a weighted average, as follows:

$$
N e w R_{f}=\frac{\left[15.5 \times\left(I M A G_{t}-C D I_{t}\right)+\left(I D A_{t}-C D I_{t}\right)\right]}{16.5}
$$

where $I M A G_{t}$ is the ANBIMA's Brazilian federal government bonds index, used here as the benchmark for the Brazilian treasury bonds market, reflecting the $I M A B_{t}$ and $I R F M_{t}$ indexes.

$$
R_{i}-R_{f}=\alpha_{i}+\beta_{i} \times\left(R_{M}-R_{f}\right)+h_{i} \times(H M L)+s_{i} \times(S M B)+w_{i} \times(W M L)+f_{i} \times\left(N e w R_{f}\right)+e_{i}
$$

\section{RESULTS AND DISCUSSION}

In this section we present and discuss the results for each of our questions.

\subsection{Do alternative assets add any kind of benefit to FIE?}

For this first question, we added 5\% of each alternative asset to our sample of FIEs rebalancing the portfolio every six months. Table 3 shows the average differences for each new portfolio over the original FIE, including all methods and their respective p-values. The first column shows that almost all assets improved the performance of FIEs with statistical significance, except for ICB (commodity index), presenting a negative $\triangle$ MPPM (-0.044\%). UTIL and IMOB indexes provided the highest average $\triangle \mathrm{MPPM}, 0.314 \%$ and $0.244 \%$, respectively. The results remain consistent in the second and fourth performance measures. On the other hand, the last column shows that the four first assets increased the tail risk (VaR), since the average $\Delta \mathrm{VaR}$ is positive, which means that the addition of these assets increased the potential losses. Given these previous findings, the Sharpe ratio analyses are mixed, presenting positive and negative results, some with statistical significance and others without. It is essential to highlight that transaction costs are crucial in this matter and the results may change depending on the costs carried by each asset.

Table 3

Average differences

\begin{tabular}{lccccccccccc}
\hline & \multicolumn{2}{c}{$\begin{array}{c}\text { Avrg } \Delta \text { MPPM over } \\
\text { original portfolio }\end{array}$} & \multicolumn{2}{c}{$\begin{array}{c}\text { Avrg } \Delta \text { alpha over } \\
\text { original portfolio }\end{array}$} & \multicolumn{2}{c}{$\begin{array}{c}\text { Avrg } \Delta \text { Sharpe over } \\
\text { original portfolio }\end{array}$} & \multicolumn{3}{c}{$\begin{array}{c}\text { Avrg } \Delta \text { origR over } \\
\text { orinal portfolio }\end{array}$} & \multicolumn{2}{c}{$\begin{array}{c}\text { Avrg } \Delta \text { VaR over } \\
\text { original portfolio }\end{array}$} \\
\hline Mean & p-val & Mean & p-val & Mean & p-val & Mean & p-val & Mean & p-val \\
\hline IMIL & $0.314 \%$ & 0.000 & $0.032 \%$ & 0.000 & $0.285 \%$ & 0.000 & $0.620 \%$ & 0.000 & $0.072 \%$ & 0.000 \\
\hline IEEX & $0.244 \%$ & 0.000 & $0.034 \%$ & 0.000 & $-0.027 \%$ & 0.418 & $0.868 \%$ & 0.000 & $0.252 \%$ & 0.000 \\
\hline IFA & $0.179 \%$ & 0.000 & $0.02 \%$ & 0.000 & $0.072 \%$ & 0.062 & $0.524 \%$ & 0.000 & $0.046 \%$ & 0.000 \\
\hline IHFA & $0.165 \%$ & 0.000 & $0.009 \%$ & 0.000 & $0.227 \%$ & 0.000 & $0.569 \%$ & 0.000 & $-0.169 \%$ & 0.000 \\
\hline Gold & $0.078 \%$ & 0.000 & $0.015 \%$ & 0.000 & $-0.148 \%$ & 0.066 & $0.252 \%$ & 0.000 & $-0.256 \%$ & 0.000 \\
\hline ICB & $-0.044 \%$ & 0.000 & $-0.003 \%$ & 0.000 & $-0.302 \%$ & 0.002 & $0.002 \%$ & 0.490 & $-0.233 \%$ & 0.000 \\
\hline
\end{tabular}

Source: Elaborated by the authors. 
Furthermore, it is worth mentioning that the factor model (used in the alpha analysis) explained most of the returns with $80.7 \%$ average adjusted $\mathrm{R}^{2}$. This average took in consideration every portfolio: UTIL (adj. $\mathrm{R}^{2}=83.4 \%$ ), IMOB (adj. $\left.R^{2}=84.2 \%\right)$, IEEX (adj. $\left.R^{2}=83.6 \%\right)$, IFA (adj. $\left.\mathrm{R}^{2}=83.9 \%\right)$, IHFA ( $\left.\mathrm{R}^{2}=80.2 \%\right)$, Gold (adj. $\left.\mathrm{R}^{2}=74.8 \%\right)$, ICB (adj. $\left.R^{2}=75.7 \%\right)$, and the original portfolio (adj. $\left.\mathrm{R}^{2}=79.9 \%\right)$.

It is intriguing that the MPPM and the factor model (alpha analysis) provided a similar ranking. The most important change occurs for UTIL and IMOB, in which the MPPM classifies UTIL as the best option and the factor model has IMOB as its first in the ranking. This result leads us to question which alternative asset is the best choice: UTIL or IMOB.

\subsection{Which alternative asset provided the greatest benefit?}

Table 4 shows statistical measures of our portfolios. In the first row we see that UTIL and IMOB presented the highest average return and that ICB was the worst in terms of return. When we observe the average return on standard deviation ratio in the fifth row, the IHFA exceeds the others, followed by the Gold and UTIL indexes. Going further down the table, we notice that IMOB more than doubled the average skewness (0.29) when compared with the original portfolio $(0.13)$. All assets reduced the average kurtosis, and almost all, not including IMOB and ICB, worsened the portfolio in terms of skewness. However, it is impossible to decide which asset outperforms others by only observing these attributes.

Table 4

Statistical measures for each asset

\begin{tabular}{|c|c|c|c|c|c|c|c|c|}
\hline & Original & UTIL & IMOB & IEEX & IFA & IHFA & Gold & ICB \\
\hline Avrg Return & $0.29 \%$ & $0.32 \%$ & $0.32 \%$ & $0.31 \%$ & $0.31 \%$ & $0.31 \%$ & $0.30 \%$ & $0.29 \%$ \\
\hline Maximum Avrg Return & $0.57 \%$ & $0.58 \%$ & $0.57 \%$ & $0.57 \%$ & $0.57 \%$ & $0.56 \%$ & $0.56 \%$ & $0.55 \%$ \\
\hline Minimum Avrg Return & $0.05 \%$ & $0.09 \%$ & $0.09 \%$ & $0.08 \%$ & $0.08 \%$ & $0.08 \%$ & $0.07 \%$ & $0.06 \%$ \\
\hline Avrg Std. Dev & $2.30 \%$ & $2.36 \%$ & $2.51 \%$ & $2.35 \%$ & $2.33 \%$ & $2.20 \%$ & $2.15 \%$ & $2.15 \%$ \\
\hline Avrg Return/Std. Dev. & $12.82 \%$ & $13.62 \%$ & $12.69 \%$ & $13.24 \%$ & $13.30 \%$ & $13.90 \%$ & $13.80 \%$ & $13.37 \%$ \\
\hline Avrg Kurtosis & 0.86 & 0.72 & 0.71 & 0.70 & 0.66 & 0.83 & 0.70 & 0.78 \\
\hline Avrg Skewness & 0.13 & 0.06 & 0.29 & 0.07 & 0.09 & 0.12 & 0.07 & 0.14 \\
\hline Avrg Carhart alpha & $0.03 \%$ & $0.07 \%$ & $0.07 \%$ & $0.06 \%$ & $0.05 \%$ & $0.04 \%$ & $0.03 \%$ & $0.02 \%$ \\
\hline
\end{tabular}

Source: Elaborated by the authors.

To facilitate the comparison between assets, we used a simple multi-criteria method, Simple Additive Weighting (SAW), to create a rank based on the results exhibited in Table 3. It involves four steps: first we need to rank all assets under each criterion (i.e., the performance measures presented in Table 3. Then, all performance results are normalized as follows:

$$
c_{i j}=\frac{P_{i j}-\min \left(P_{j}\right)}{\max \left(P_{j}\right)-\min \left(P_{j}\right)}
$$

where $c_{i j}$ is the normalized measure of asset $\mathrm{i}$ with respect to a performance measure $\mathrm{j}(\mathrm{i}=$ IHFA and $\mathrm{j}=$ modified Sharpe, for example), $\boldsymbol{P}_{i j}$ is the performance result of asset $i$ for the performance measure $j$, and max (or $\min )\left(\boldsymbol{P}_{j}\right)$ is the maximum (or minimum) value under the performance measure $j$. After that, we convert the normalized ranking into numerical weights, using the Rank-Order Centroid method that minimizes the maximum error of each weight by uniformly distributing them:

$$
w_{i j}=\frac{1}{n} \sum_{r_{i j}=k}^{n} \frac{1}{k}
$$

where $w_{i j}$ is the weight of asset $i$ for a given performance measure $j, n$ is the number of assets and $r_{i j}$ is the asset position in the ranking for the performance measure $j$. In the end, we take the weighted average for all assets. Table 5 shows all assets ranked by their respective SAW score. Just like the ranking provided by the MPPM method, the UTIL index presented the highest score among the others, followed by the IMOB index. The hedge fund index (IHFA) became the third best option, which may be related to its strong risk-return relation. Readers should be cautious when analyzing this ranking, as some assets are highly correlated and may affect it, which is the case of UTIL and IEEX indexes. 
Table 5

Assets ranking

\begin{tabular}{lcc}
\hline Assets & SAW Score & Ranking Position \\
\hline UTIL & 1.14 & 1 \\
\hline IMOB & 0.96 & 2 \\
\hline IHFA & 0.49 & 3 \\
\hline Gold & 0.46 & 4 \\
\hline IEEX & 0.35 & 5 \\
\hline IFA & 0.34 & 6 \\
\hline ICB & 0.22 & 7 \\
\hline
\end{tabular}

Source: Elaborated by the authors.

Developing a rank using ten years of data can lead to a bias, where luck strategies may be favored, leading to misinterpretation of results. For instance, suppose an asset provided a colossal performance improvement in 2010 due to an external factor, leading us to the conclusion that this asset contributes positively to the FIEs performance. However, if we break this period, we can observe that this asset failed to improve the FIEs performance in the following years. In fact, this result was biased by the impact of the external factor. Therefore, to address this issue we went further, dividing our analysis into different time periods. This analysis may support strategies such as Smart Beta, which uses fundamentalist analysis and is influenced by macroeconomic factors.

We found that UTIL and IEEX are the only assets providing positive benefits in all market states, as seen in Table 6. The UTIL index is an important indicator since the sector covered by it supplies basic needs. Historically, the public utility sector has always been a significant part of Brazilian industry and, along with the extractive sector, has presented consistent results over the years.

Surprisingly, the UTIL strategy was the best in the 2014-2016 recession $(\triangle \mathrm{MPPM}=0.275 \%)$. This result is strongly related to the hydric crisis in early 2014 considered one of the worst in Brazilian history -, which increased the value of water and related services, e.g., energy, water distribution and basic sanitation.

Furthermore, productivity growth remains a top priority for Brazil, and greater investments in infrastructure will be needed, representing a great opportunity for this sector. According to the National Confederation of Industry (CNI, 2019), the share of industry in the Brazilian GDP grew from 21\% to 22\% between 2017 and 2018. This growth was driven, partially, by the increased participation of the public utility sector in GDP (from $2.6 \%$ to $2.8 \%$ ), explaining the benefit brought by the UTIL index in the last years $(\triangle \mathrm{MPPM}=0.493 \%)$.

IMOB provided the greatest benefit in the first two columns $(\triangle \mathrm{MPPM}=1.717 \%$ and $\triangle \mathrm{MPPM}=0.526 \%)$. The success of the real state sector in this period was due to the launch of the governmental program Minha Casa, Minha Vida (the largest housing program ever created in Brazil) in 2009, focused on subsidizing the construction or purchase of thousands of houses for low-income habitants.

After it, Brazil suffered the greatest recession in its history, caused by the drop in commodity prices and the limited capacity to perform the necessary fiscal reforms at all government levels, bringing instability and political mistrust for the following years. Looking to the sell side, this sector presents a long construction cycle and any investment in that period would represent an enormous risk for new ventures. For the buyer, the unemployment risk would lead to the postponement of the purchase of a high value asset. This scenario thus reflects the bad results of the IMOB strategy in the 2014-2016 recession $(\triangle \mathrm{MPPM}=-0.615 \%)$. In the recovery period (2017 and $2018)$, it began to bounce back ( $\triangle M P P M=0.438 \%)$, showing that the real estate sector is strongly attached to the Brazilian economy.

The electric power sector follows the same pattern as the UTIL index, given that it is part of the public utility services sector. However, in the growth phase, the IEEX presented the second worst performance improvement when compared with the others $(\triangle \mathrm{MPPM}=0.111 \%)$. This may be related to the implementation of the Provisional Measure 579 in 2012, which determined the reduction of tariffs and the renewal of electric power generation, transmission and distribution concessions. It reduced the offer of electric power, forcing distributors to pay a higher price for its supply. The electric power sector, previously seen as a defensive option due to its predictability, registered strong losses in that period. Nonetheless, this index still improved the performance of FIEs in all market states.

The equity mutual funds suffered strong drops in the recession period (2014-2016), caused mainly by the increase in investors risk aversion. A massive wave of redemptions occurred during that period, reducing the net worth of these funds and explaining the loss in FIEs performance $(\triangle \mathrm{MPPM}=-0.358 \%)$. 
Table 6

Market states analysis

\begin{tabular}{|c|c|c|c|c|c|c|c|c|}
\hline & \multicolumn{2}{|c|}{$\begin{array}{c}\text { Recession } \\
\text { Jan-2009 / Mar-2009 }\end{array}$} & \multicolumn{2}{|c|}{$\begin{array}{c}\text { Growth } \\
\text { Apr-2009 / Mar-2014 }\end{array}$} & \multicolumn{2}{|c|}{$\begin{array}{c}\text { Recession } \\
\text { Apr-2014 / Dec-2016 }\end{array}$} & \multicolumn{2}{|c|}{$\begin{array}{c}\text { Slow Recovery } \\
\text { Jan-2017 / Dec-2018 }\end{array}$} \\
\hline & $\triangle \mathrm{MPPM}$ & p-val & $\triangle \mathrm{MPPM}$ & p-val & $\triangle \mathrm{MPPM}$ & p-val & $\triangle \mathrm{MPPM}$ & p-val \\
\hline UTIL & $0.523 \%$ & 0.000 & $0.254 \%$ & 0.000 & $0.275 \%$ & 0.000 & $0.493 \%$ & 0.000 \\
\hline IMOB & $1.717 \%$ & 0.000 & $0.526 \%$ & 0.000 & $-0.615 \%$ & 0.000 & $0.438 \%$ & 0.000 \\
\hline IEEX & $0.699 \%$ & 0.000 & $0.111 \%$ & 0.297 & $0.269 \%$ & 0.000 & $0.273 \%$ & 0.000 \\
\hline IFA & $0.396 \%$ & 0.000 & $0.186 \%$ & 0.000 & $-0.358 \%$ & 0.000 & $0.873 \%$ & 0.000 \\
\hline IHFA & $-0.195 \%$ & 0.000 & $0.240 \%$ & 0.000 & $0.232 \%$ & 0.000 & $-0.072 \%$ & 0.000 \\
\hline Gold & $-0.183 \%$ & 0.000 & $0.058 \%$ & 0.000 & $0.039 \%$ & 0.000 & $0.215 \%$ & 0.000 \\
\hline ICB & $-2.375 \%$ & 0.000 & $0.119 \%$ & 0.000 & $-0.060 \%$ & 0.008 & $-0.163 \%$ & 0.000 \\
\hline
\end{tabular}

Source: Elaborated by the authors.

Another interesting asset to analyze is IHFA, which is expanding in Brazil and presented the third best result for the 2014-2016 recession $(\triangle M P P M=0.232 \%)$. Its negative result in $2009(\triangle \mathrm{MPPM}=-0.195 \%)$ and in the slow recovery period $(\triangle \mathrm{MPPM}=-0.072 \%)$ can be explained by trend changes occurring faster than expected, such as the subprime crisis in 2009 and the strike of truck drivers in 2018, which seriously impacted the market. However, it was not enough to make this asset a bad choice - as seen previously in Table 3, it provided benefits in all aspects of the portfolio.

The portfolios with the gold index presented one of the worst performances in the 2009 recession $(\triangle M P P M=$ $-0.183 \%)$. The explanation for this is that gold is quoted in dollars (USD). Therefore, if USD appreciates against BRL the price of gold will rise and the opposite will occur if BRL appreciates against USD. Following the subprime crisis in 2008, BRL appreciated against USD, causing a drop in the price of gold in Brazil.

Commodities represent a large proportion of the Brazilian export sector and it was drastically affected by the subprime crisis in 2009, resulting in an expressive drop $(\triangle \mathrm{MPPM}=-2.375 \%)$. However, during the growth phase $(\triangle M P P M=0.119 \%)$, the exports to China increased exponentially. After this period, the price of commodities began to drop, consolidating the economic recession and poor performance in the following years $(\triangle \mathrm{MPPM}=$ $-0.060 \%$ and $\triangle \mathrm{PMPM}=-0.163 \%$ ).

After analyzing our assets with multiple metrics and over different time periods, it seems reasonable to state that the UTIL index is the best option in terms of performance benefits. To better vizualize it, we compared the two best positioned assets - IMOB and UTIL - in graph form and ranked by the SAW method and the MPPM, considering the average return and standard deviation of each fund (Figure 1). It is easy to see that most funds had a better average return with the addition of UTIL compared to IMOB. Also, for each fund, the standard deviation of returns decreased significantly, showing that UTIL provided a better diversification than IMOB.

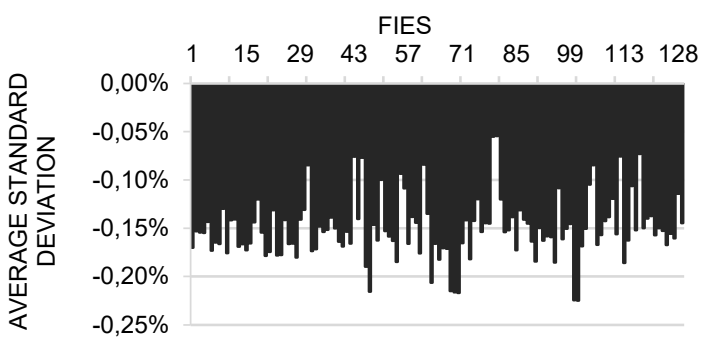

Figure 1 Difference between UTIL and IMOB

Source: Elaborated by the authors.

We also compared the FIEs (composed by $5 \%$ of UTIL index) against the portfolios with the other assets (composed by $5 \%$ of each asset). Table 7 shows that the difference between UTIL and the other assets are significant. 
Table 7

UTIL against other assets

\begin{tabular}{lcccccccccc}
\hline & \multicolumn{2}{c}{$\begin{array}{c}\text { Avrg } \Delta \text { MPPM over } \\
\text { UTIL index }\end{array}$} & \multicolumn{2}{c}{$\begin{array}{c}\text { Avrg } \Delta \text { alpha over UTIL } \\
\text { index }\end{array}$} & \multicolumn{2}{c}{$\begin{array}{c}\text { Avrg } \Delta \text { Sharpe over } \\
\text { UTIL index }\end{array}$} & \multicolumn{2}{c}{$\begin{array}{c}\text { Avrg } \Delta \text { UPR over UTIL } \\
\text { index }\end{array}$} & \multicolumn{2}{c}{$\begin{array}{c}\text { Avrg } \Delta \text { VaR over UTIL } \\
\text { index }\end{array}$} \\
\hline & Mean & p-val & Mean & p-val & Mean & p-val & Mean & p-val & Mean & p-val \\
\hline IMOB & $-0.070 \%$ & 0.000 & $0.002 \%$ & 0.000 & $-0.312 \%$ & 0.000 & $0.247 \%$ & 0.002 & $-0.179 \%$ & 0.000 \\
\hline IEEX & $-0.113 \%$ & 0.000 & $-0.004 \%$ & 0.000 & $-0.248 \%$ & 0.000 & $-0.193 \%$ & 0.000 & $-0.009 \%$ & 0.049 \\
\hline IFA & $-0.135 \%$ & 0.000 & $-0.010 \%$ & 0.000 & $-0.212 \%$ & 0.000 & $-0.489 \%$ & 0.000 & $0.026 \%$ & 0.001 \\
\hline IHFA & $-0.149 \%$ & 0.000 & $-0.023 \%$ & 0.000 & $-0.058 \%$ & 0.269 & $-0.096 \%$ & 0.025 & $0.241 \%$ & 0.000 \\
\hline Gold & $-0.236 \%$ & 0.000 & $-0.017 \%$ & 0.000 & $-0.433 \%$ & 0.000 & $-0.369 \%$ & 0.000 & $0.328 \%$ & 0.000 \\
\hline ICB & $-0.358 \%$ & 0.000 & $-0.035 \%$ & 0.000 & $-0.587 \%$ & 0.000 & $-0.619 \%$ & 0.000 & $0.305 \%$ & 0.000 \\
\hline
\end{tabular}

Source: Elaborated by the authors.

Despite being the best one in terms of performance improvement, the UTIL index did not show improvement in the tail risk measure as seen in the last column. Thus, since the IHFA index drew our attention and curiosity - being the only asset to provide benefits in all methods - we decided to combine both assets, dividing the $5 \%$ between them.

Figure 2 demonstrates what happens when we mix the two assets. The more we add IHFA to the current

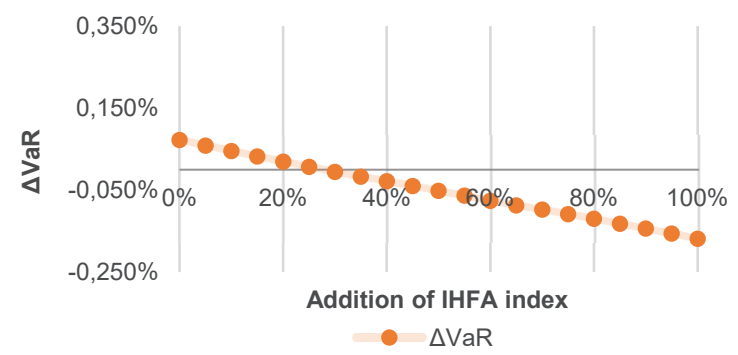

Figure 2 Combination of IHFA and UTIL indexes

Source: Elaborated by the authors.

\subsection{Does the MPPM have a better persistence over time than alpha?}

Table 8 presents the slope coefficients of the stacked regression for different windows sizes. Here, crosssectional $\triangle$ MPPM (alphas) estimated for the first half of the window $(24,48,60$ months) are regressed on cross-section $\triangle$ MPPM (alphas) for the second half of the window. fund portfolio, the lower the performance enhancement. However, the improvement in the tail risk is much more pronounced. For instance, if we use only the UTIL index, the $\triangle \mathrm{MPPM}$ will be equal to $0.314 \%$ and the $\triangle \mathrm{VaR}$ equal to $0.072 \%$. On the other hand, if we use $30 \%$ of the IHFA along with $70 \%$ of the UTIL index, performance $(\triangle \mathrm{MPPM})$ will be reduced to $0.270 \%$ (a $14 \%$ decrease) and tail risk ( $\Delta \mathrm{VaR}$ ) will improve to $-0.006 \%$ (a $108 \%$ enhancement).

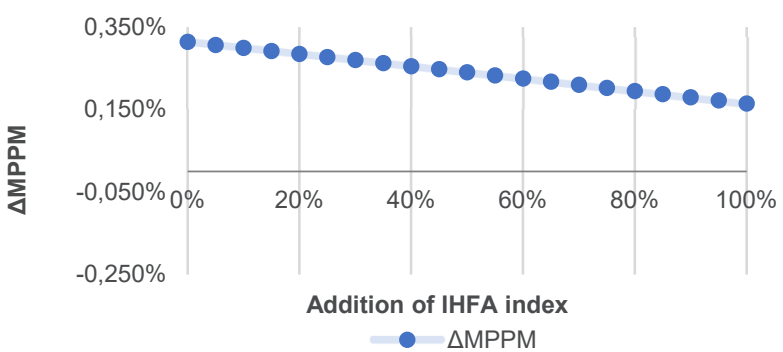

Although MPPM proved to be a better mhod for ranking purposes, it did not show persistence over time. In contrast, the factor model demonstrated significant persistence for the 12 month-window, but for larger periods there was no persistence. The anti-persistence for longer periods can be due to mean reversion in estimated performance measures.

Table 8

Persistence analysis

\begin{tabular}{lcccc}
\hline Window size [first half (formation period) & \multicolumn{2}{c}{$\Delta$ MPPM } & \multicolumn{2}{c}{$\Delta$ alpha } \\
\cline { 2 - 5 } / second half (evaluation period)] & $\boldsymbol{b}_{\text {MPPM }}$ & t-stat & $\boldsymbol{b}_{\boldsymbol{\alpha}}$ & 0.14 \\
\hline 12 months / 12 months & -0.39 & -14.05 & -0.77 & 4.99 \\
\hline 24 months / 24 months & -0.01 & -0.16 & -0.76 & -12.82 \\
\hline 30 months / 30 months & -0.54 & -9.38 & -25.33 \\
\hline
\end{tabular}

Source: Elaborated by the authors. 


\section{ROBUSTNESS}

Several robustness tests were made for the main results. First, to check if the risk-aversion parameter $(\rho)$ was a good estimate for our study, we varied it from 0.85 to 2 and 3 . We believe that the 0.85 parameter was a fair estimate since the Brazilian economy was regaining market confidence due to the result of the 2018 presidential elections. The increase in the parameter estimate means that the risk aversion is increasing, which could happen in the near future if the government fails to take the necessary steps to restore fiscal sustainability.

Table 9 presents the results for these changes, showing that the average $\triangle \mathrm{MPPM}$ changed slightly and remained strongly significant. The UTIL strategy remained the first in the ranking, demonstrating its stability. For the IMOB strategy, the change in risk-version parameter severely penalized its performance, showing that it is more exposed to risk than the others. This change had positive effect in other cases, which is the case of the IHFA strategy becoming the second-best option in terms of $\triangle \mathrm{MPPM}$. This appears to be a fair result since the hedge fund industry seeks protection in a risky environment. The same happens to the Gold strategy.

Table 9

Different risk-aversion values

\begin{tabular}{|c|c|c|c|c|c|c|}
\hline & \multicolumn{2}{|c|}{$\begin{array}{l}\text { Avrg } \triangle \text { MPPM over original portfolio with } \\
\qquad \rho=0.85\end{array}$} & \multicolumn{2}{|c|}{$\begin{array}{l}\text { Avrg } \triangle \text { MPPM over original portfolio with } \\
\qquad \rho=2\end{array}$} & \multicolumn{2}{|c|}{$\begin{array}{c}\text { Avrg } \triangle \text { MPPM over original portfolio with } \\
\qquad \rho=3\end{array}$} \\
\hline & Mean & p-value & Mean & p-value & Mean & p-value \\
\hline UTIL & $0.31 \%$ & 0.00 & $0.30 \%$ & 0.00 & $0.29 \%$ & 0.00 \\
\hline IMOB & $0.24 \%$ & 0.00 & $0.19 \%$ & 0.00 & $0.14 \%$ & 0.00 \\
\hline IEEX & $0.20 \%$ & 0.00 & $0.19 \%$ & 0.00 & $0.18 \%$ & 0.00 \\
\hline IFA & $0.18 \%$ & 0.00 & $0.18 \%$ & 0.00 & $0.17 \%$ & 0.00 \\
\hline IHFA & $0.16 \%$ & 0.00 & $0.20 \%$ & 0.00 & $0.24 \%$ & 0.00 \\
\hline Gold & $0.08 \%$ & 0.00 & $0.14 \%$ & 0.00 & $0.19 \%$ & 0.00 \\
\hline ICB & $-0.04 \%$ & 0.00 & $0.01 \%$ & 0.10 & $0.06 \%$ & 0.00 \\
\hline
\end{tabular}

Source: Elaborated by the authors.

Our second robustness test was based on applying different weights in the addition of alternative assets. We modeled the main results using $5 \%$ of each asset and for this test and varied the weight of each alternative asset from $1 \%$ to $8 \%$. Table 10 shows the same main results as Table 3 but with different weights. We applied the semiannual portfolio rebalancing for the $1 \%$ strategy, but for the $8 \%$ strategy it was needed to rebalance it monthly. This was necessary because the addition of some assets exceeded the $10 \%$ limit in the first month, which was the case of IMOB in 2009. The $1 \%$ and 5\% strategies were not rebalanced monthly because the rebalancing period is fundamental given the transaction costs involved. Therefore, we prefer the semi-annual rebalancing (with lower costs) instead of rebalancing the FIE's portfolios monthly (with higher costs).

The results remained very stable and statistically significant. The ranking in MPPM terms did not change and one can observe that the higher the weight, the better the improvement in the portfolio. When we reduce the weight ( $1 \%$ strategy), the results were significantly lower than the $5 \%$ and $8 \%$ strategies. For instance, in the first column the UTIL portfolio decreased by $80 \%$ when compared to the 5\% strategy, going from $0.314 \%$ (Table 3) to $0.063 \%$.

Some assets, such as UTIL and IHFA, can be rebalanced every six months with the $8 \%$ strategy without exceeding the regulation limit. 
Table 10

Main results with different weights

\begin{tabular}{|c|c|c|c|c|c|c|c|c|c|c|c|}
\hline \multirow[t]{2}{*}{ Weights } & & \multicolumn{2}{|c|}{$\begin{array}{l}\text { Avrg } \triangle \mathrm{MPPM} \text { over } \\
\text { original portfolio }\end{array}$} & \multicolumn{2}{|c|}{$\begin{array}{c}\text { Avrg } \Delta \text { alpha } \\
\text { over original } \\
\text { portfolio }\end{array}$} & \multicolumn{2}{|c|}{$\begin{array}{c}\text { Avrg } \Delta \text { Sharpe } \\
\text { over original } \\
\text { portfolio }\end{array}$} & \multicolumn{2}{|c|}{$\begin{array}{c}\text { Avrg } \Delta U P R \\
\text { over original } \\
\text { portfolio }\end{array}$} & \multicolumn{2}{|c|}{$\begin{array}{c}\text { Avrg } \Delta \mathrm{VaR} \\
\text { over original } \\
\text { portfolio }\end{array}$} \\
\hline & & Mean & p-val & Mean & p-val & Mean & p-val & Mean & p-val & Mean & p-val \\
\hline \multirow{7}{*}{$\begin{array}{l}1 \% \\
\text { strategy }\end{array}$} & UTIL & $0.063 \%$ & 0.000 & $0.006 \%$ & 0.000 & $0.076 \%$ & 0.000 & $0.104 \%$ & 0.000 & $0.017 \%$ & 0.000 \\
\hline & IMOB & $0.051 \%$ & 0.000 & $0.007 \%$ & 0.000 & $0.032 \%$ & 0.023 & $0.157 \%$ & 0.000 & $0.045 \%$ & 0.000 \\
\hline & IEEX & $0.041 \%$ & 0.000 & $0.006 \%$ & 0.000 & $0.032 \%$ & 0.010 & $0.061 \%$ & 0.000 & $0.016 \%$ & 0.000 \\
\hline & IFA & $0.036 \%$ & 0.000 & $0.004 \%$ & 0.000 & $0.031 \%$ & 0.005 & $0.024 \%$ & 0.001 & $0.010 \%$ & 0.000 \\
\hline & IHFA & $0.033 \%$ & 0.000 & $0.002 \%$ & 0.000 & $0.044 \%$ & 0.000 & $0.088 \%$ & 0.000 & $-0.034 \%$ & 0.000 \\
\hline & Gold & $0.016 \%$ & 0.000 & $0.003 \%$ & 0.000 & $-0.005 \%$ & 0.355 & $0.014 \%$ & 0.294 & $-0.057 \%$ & 0.000 \\
\hline & ICB & $-0.010 \%$ & 0.000 & $-0.001 \%$ & 0.000 & $-0.048 \%$ & 0.004 & $-0.025 \%$ & 0.178 & $-0.051 \%$ & 0.000 \\
\hline \multirow{7}{*}{$\begin{array}{l}8 \% \\
\text { strategy }\end{array}$} & UTIL & $0.488 \%$ & 0.000 & $0.050 \%$ & 0.000 & $0.470 \%$ & 0.000 & $1.081 \%$ & 0.000 & $0.154 \%$ & 0.000 \\
\hline & IMOB & $0.334 \%$ & 0.000 & $0.046 \%$ & 0.000 & $-0.130 \%$ & 0.251 & $1.265 \%$ & 0.000 & $0.447 \%$ & 0.000 \\
\hline & IEEX & $0.323 \%$ & 0.000 & $0.046 \%$ & 0.000 & $0.077 \%$ & 0.266 & $0.841 \%$ & 0.000 & $0.171 \%$ & 0.000 \\
\hline & IFA & $0.272 \%$ & 0.000 & $0.034 \%$ & 0.000 & $0.073 \%$ & 0.204 & $0.219 \%$ & 0.000 & $0.085 \%$ & 0.000 \\
\hline & IHFA & $0.261 \%$ & 0.000 & $0.013 \%$ & 0.000 & $0.369 \%$ & 0.000 & $0.885 \%$ & 0.000 & $-0.269 \%$ & 0.000 \\
\hline & Gold & $0.174 \%$ & 0.000 & $0.031 \%$ & 0.000 & $-0.161 \%$ & 0.132 & $0.613 \%$ & 0.000 & $-0.375 \%$ & 0.000 \\
\hline & ICB & $-0.202 \%$ & 0.000 & $-0.008 \%$ & 0.000 & $-0.843 \%$ & 0.000 & $-0.030 \%$ & 0.383 & $-0.260 \%$ & 0.000 \\
\hline
\end{tabular}

Source: Elaborated by the authors.

The last robustness test is related to a concern about the eight-factor model. Instead of using the eight-factor model, we reduced it to only five factors by taking out the IML factor and creating the new risk-free factor, as explained in the methodology section. The five-factor model showed to be marginally inferior since its explanation power was lower when compared to the eight-factor model (79.3\% average adjusted $\mathrm{R}^{2}$ against $80.7 \%$ ). This average took in consideration every portfolio: UTIL (adj. $\mathrm{R}^{2}=82.3 \%$ ),
IMOB (adj. $\mathrm{R}^{2}=83.2 \%$ ), IEEX (adj. $\left.\mathrm{R}^{2}=82.4 \%\right)$, IFA (adj. $\mathrm{R}^{2}=82.6 \%$ ), IHFA (adj. $\mathrm{R}^{2}=78.5 \%$ ), Gold (adj. $\mathrm{R}^{2}=73.5 \%$ ), and the original portfolio (adj. $\mathrm{R}^{2}=78.2 \%$ ).

Table 11 shows the comparison between both models in terms of average $\Delta$ alpha over the original FIEs portfolios. The ranking almost remained the same and the results changed very little, except for the Gold strategy in the five-factor column, which presented a non-statistically significant $\Delta$ alpha $(\mathrm{p}$-value $=0.135)$.

Table 11

Five-factor model against eight factor model

\begin{tabular}{lcccc}
\hline & \multicolumn{2}{c}{ Avrg $\Delta$ alpha over original portfolio } & \multicolumn{2}{c}{$\begin{array}{c}\text { Avrg } \Delta \text { alpha over original portfolio } \\
\text { (eight-factor model) }\end{array}$} \\
\hline IMOB & Mean & p-value & Mean & p-value \\
\hline UTIL & $0.042 \%$ & 0.000 & $0.034 \%$ & 0.000 \\
\hline IEEX & $0.030 \%$ & 0.000 & $0.032 \%$ & 0.000 \\
\hline IFA & $0.026 \%$ & 0.000 & $0.028 \%$ & 0.000 \\
\hline Gold & $0.019 \%$ & 0.000 & $0.02 \%$ & 0.000 \\
\hline IHFA & $0.001 \%$ & 0.135 & $0.015 \%$ & 0.000 \\
\hline ICB & $0.009 \%$ & 0.000 & $0.009 \%$ & 0.000 \\
\hline
\end{tabular}

Source: Elaborated by the authors.

In short, these results corroborate the previous conclusion: the addition of alternative assets improves the performance of FIEs and the performance measures used (MPPM and eight factor model) provide very robust results. 


\section{CONCLUSION}

Historically, the Brazilian specially constituted investment funds (FIEs) of PGBL and VGBL have always been dependent on fixed income assets. However, the decrease of the Brazilian standard rate (Selic) is forcing fund managers to search for other alternatives. Still, little have been studied whether alternative assets have any positive effect on FIEs performances. We advocate the use of the Manipulation-Proof Performance Measure (MPPM) method for performance measurement; this method provided the most similar ranking when compared to the ranking generated by the Simple Additive Weighting (SAW) method. The literature states that MPPM is much more robust when compared to other traditional measures: Sharpe Ratio, Upside Potential Ratio, and any factor model. All methods have flaws that may lead to misinterpretation of the results, such as assumption of symmetrically distributed returns and poorly estimated parameters. Nevertheless, the factor model showed to have a better persistence over time when compared to the MPPM.

Respecting Brazilian regulations and using a large database of FIEs returns from January 2009 to December 2018 , this study analyzed strategies of investing in $5 \%$ of an alternative asset and $95 \%$ in the current fund portfolio and compare it to the strategy of investing in $100 \%$ of these funds' portfolios, rebalancing the portfolio every six months. We found that the UTIL index outperformed the others, improving the average fund performance by $0.523 \% \triangle \mathrm{MPPM}$, which is superior to adding the ANBIMA's hedge funds index (IHFA), Brazilian Central Bank's equity mutual funds index (IFA), B3's commodity index (ICB), B3's electric power index (IEEX), B3's gold index (OZ1D), and a proxy of real estate investments, $B 3$ 's real estate index (IMOB).

When we divided our analysis into different market states, some assets outperformed the UTIL index during specific periods due to certain peculiarities such as the launch of the governmental program Minha Casa Minha Vida, which favored the IMOB index in 2009. However, when we look at all periods, UTIL and IEEX were the only assets to provide benefits in every market state, highlighting the first one as an asset that provided the greatest improvement during the worst recession of the Brazilian history (from April 2014 to December 2016), with $0.275 \% \triangle \mathrm{MPPM}$. The IHFA index was interesting because it was the only asset to provide benefits in all aspects of the portfolio, including tail risk $(\Delta \mathrm{VaR}=0.169 \%)$. Thus, when we combine both assets, UTIL and IHFA, we find that the addition of IHFA reduces the performance improvement, but the tail risk improvement is much more pronounced.

The performance improvement generated by the addition of alternative assets are much more accentuated when we increase the weight from $5 \%$ to $8 \%$. However, the transaction costs may increase since the need for a shorter period of rebalancing is required. Interestingly, IHFA and UTIL can still be rebalanced every six months with the $8 \%$ strategy without exceeding the regulation limit.

Although our results are only valid to the sample used, it builds upon international literature, which presents similar results and provides robustness to our results. Several studies worldwide have shown that alternative assets can improve the performance of traditional asset portfolios, including pension funds portfolios. We cite just a few of them that corroborate our results: Daskalaki et al. (2017), Jackwerth and Slavutskaya (2016), Costa et al. (2014), Belousova and Dorfleitner (2012), Leal and Mendes 2009, Costa and Piacenti (2008), Davis (2005), and Favre and Galeano (2002). Furthermore, our results also demonstrated robustness to a wide range of changes in the methodology. For future studies we suggest that transaction costs could be included to check if the performance improvement brought by these assets do overcome the costs. To enrich the literature and provide different comparisons, more assets could be used, such as, private equity and foreign equities. Moreover, the use of indexes is still considered a passive strategy and an analysis using an active strategy could be performed to test whether it would be more beneficial.

There is evidence that alternative assets can bring benefits to FIEs portfolios and that the current economic scenario favors alternative investments. Therefore, we question: are fund managers prepared and willing to take risks in this competitive market? We cannot answer this question yet, but we hope our study can assist them in this challenge. 


\section{REFERENCES}

Amin, G., \& Kat, H. (2003a). Hedge fund performance 1990200: Do the "money machines" really add value? Journal of Financial and Quantitative Analysis, 28(2), 251-274.

Amin, G., \& Kat, H. (2003b). Stocks, bonds and hedge funds: Not a Free Lunch! Journal of Portfolio Management, 29, 113-120.

Andonov, A., Kok, N., \& Eichholtz, P. (2013). A Global perspective on pension fund investments in real estate. The Journal of Portfolio Management, 39(5), 32-42.

Bali, T. G., Brown, S. J., \& Demirtas, K. O. (2013) Do hedge funds outperform stocks and bonds? Management Science, 59(8), 1887-1903.

Becker, B., \& Ivashina, V. (2015). Reaching for yield in the bond market. Journal of Finance, 70(5), 1863-1902.

Belousova, J., \& Dorfleitner, G. (2012). On the diversification benefits of commodities from the perspective of euro investors. Journal of Banking \& Finance, 36(9), 2455-2472.

Bessler, W., \& Wolff, D. (2015). Do commodities add value in multi-asset portfolios? An out-of-sample analysis for different investment strategies. Journal of Banking \& Finance, 60, 1-20.

Brazilian Center for Research in Financial Economics of the University of São Paulo (Nefin). Accessed on 27 February 2019: http://www.nefin.com.br/.

Campani, C. H., \& Brito, L. M. (2018). Fundos de previdência privada: passividade a preços de fundos ativos. Revista de Contabilidade e Finanças, 29(76), 148-163.

Campani, C. H., \& Costa, T. R. D. (2016). Pensando na aposentadoria: PGBL, VGBL e autoprevidência. Relatórios Coppead, 428, 1-37. Retrieved from https://www.coppead.ufrj. br/upload/publicacoes/428.pdf

Campani, C. H., \& Soares, W. C. (2019). Performance Analysis of PGBL and VGBL Retirement Funds. COPPEAD School of Business Working paper.

Catalão, A., \& Yoshino, J. (2004). The Equity Premium Puzzle: Estados Unidos e Brasil. (Master Thesis). Universidade de São Paulo, São Paulo, Brazil. Retrieved from http://www.econ.fea. usp.br/seminarios/artigos/joe_ipe.pdf.

Conti, B. (2016). Os fundos brasileiros de previdência complementar: Segmentações analíticas e estudos preliminares sobre a alocação de seus recursos. Instituto de Pesquisa Econômica Aplicada. Texto para Discussão. Retrieved from: http://hdl.handle.net/10419/129897.

Costa, T. M. T, \& Piacenti, C. A. (2008). Utilização de contratos futuros agropecuários no perfil médio de investimentos dos fundos de pensão no Brasil. Revista Contabilidade \& Finanças, 19(46), 59-72.

Costa, T. M. T., Santos, M. L., \& Silveira, S. F. R. (2014). Utilização de contratos futuros do Ibovespa em carteiras de fundos de pensão no Brasil: uma abordagem setorial. Revista de Ciências da Administração, 16(38), 110-125.

Daskalaki, C., Skiadopoulos, G., \& Topaloglou, N. (2017). Diversification benefits of commodities: A stochastic dominance efficiency approach. Journal of Empirical Finance, 44, 250-269.
Davis, E. P. (2005). Pension fund management and international investment - a global perspective. Pensions: An International Journal, 10(3), 236-261.

Favre, L., \& Galeano, J.-A. (2002). An analysis of hedge fund performance using loess fit regression. The Journal of Alternative Investments, 4(4), 8-24.

FenaPrevi (2018). Coberturas de pessoas: planos de acumulação. Retrieved from http://fenaprevi.org.br/fenaprevi/estatisticas.

Goetzmann, W. N., Ingersoll, J., Spiegel, M., \& Welch, I. (2007). Portfolio performance manipulation and manipulation-proof performance measures. Review of Financial Studies, 20(5), 1503-1546.

Gregoriou, G. N, \& Rouah, F. (2002). The role of hedge funds in pension fund portfolios: Buying protection in bear markets. Pensions: An International Journal, 7(3), 237-245.

Gutierrez, T., Pagnoncelli, B., Valladão, D., \& Cifuentes, A. (2019). Can asset allocation limits determine portfolio risk-return profiles in DC pension schemes? Insurance: Mathematics and Economics, 86, 134-144.

Harris, R. S., Jenkinson, T., \& Kaplan, S. N. (2014). Private equity performance: what do we know? The Journal of Finance, 69(5), 1851-1882.

Israelsen, C. (2005). A refinement to the Sharpe ratio and information ratio. Journal of Asset Management, 5(6), 423427.

Jackwerth, J. C.; \& Slavutskaya, A. (2016). The total benefit of alternative assets to pension fund portfolios. Journal of Financial Markets, 31, 25-42.

Kräussl, R., Lehnert, T., \& Rinne, K. (2017). The search for yield: implications to alternative investments. Journal of Empirical Finance, 44, 227-236. Retrieved from https://ssrn.com/ abstract $=3066673$.

Leal, R. P. C., \& Mendes, B. V. M. (2009). A relação risco-retorno de fundos de pensão com investimentos em hedge funds. Relatórios Coppead. Retrieved from https://www.coppead.ufrj. br/upload/publicacoes/383completo.pdf.

Lopes, A. B., \& Furtado, C. V. (2006). Private equity na carteira de investimentos das entidades de previdência privada. Revista Contabilidade \& Finanças, 17(2), 108-126.

National Confederation of Industry (CNI). (2019). A indústria em números. Retrieved from http://www.portaldaindustria.com. br/estatisticas/industria-em-numeros/.

Newell, G., \& Peng, H. W. (2008). The role of U. S. infrastructure in investment portfolios. The Journal of Real Estate Portfolio Management, 14(1), 21-34. Retrieved from https://www.jstor. org/stable/24883127.

Nielsen, K. M. (2011). The return to direct investment in private firms: new evidence on the private equity premium puzzle. European Financial Management, 17(3), 436-463.

Organization for Economic Co-operation and Development (OECD). (2018). Pension markets in focus. Retrieved from http://www.oecd.org/daf/fin/private-pensions/PensionMarkets-in-Focus-2018.pdf. 
Ornelas, J. R. H.; Silva JR., A.F.A., \& Farias, A. R. (2008). Manipulation-proof performance evaluation of Brazilian fixed income and multimarket funds. Working paper.

Platanakis, E., Sakkas, A., \& Sutcliffe, C. (2018). Harmful diversification: Evidence from alternative investments. The British Accounting Review, 51(1), 1-23.

Silva, R. B., Moreira, R. M., \& Motta, L. F. J. (2009). Impacto da aplicação em ativos internacionais no desempenho dos Fundos de Pensão no Brasil. Revista Brasileira de Finanças, 7(2), 237258. Retrieved from http://www.spell.org.br/documentos/ ver/4489/impacto-da-aplicacao-em-ativos-internacionais-nodesempenho-dos-fundos-de-pensao-no-brasil.

Sortino, F. A., van der meer, R. A. H.; \& Plantinga, A. (1999). The Dutch triangle - a framework to measure upside potential relative to downside risk. Journal of Portfolio Management, 26(1), 50-57.

Superintendência de Seguros Privados (Susep). (2015). Fundos de Investimentos no Mercado de Previdência Privada
Aberta e de Seguros de Sobrevivência. Available at: http:// blog.congressoanbimadefundos.com.br/wp-content/ uploads/2015/05/20_paralela_Previdencia_Denis.pdf.

Superintendência de Seguros Privados (Susep). (2018). $6^{\circ}$ Relatório de Análise e Acompanhamento dos Mercados Supervisionados. Retrieved from http://www.susep.gov.br/ menuestatistica/SES/6 b0\%20Relat_Acomp_Mercado_2018. pdf.

Superintendência de Seguros Privados (Susep). Susep's Statistical System (SES). Retrieved from: http://www2.susep.gov.br/ menuestatistica/SES/principal.aspx

Willis Towers Watson. (2017). Global Alternative Survey.

Retrieved from https://www.willistowerswatson.com/-/media/ WTW/PDF/Insights/2017/07/Global-Alternatives-Survey2017-Final.pdf.

Willis Towers Watson. (2018). Global Pension Assets Study. Retrieved from https://www.willistowerswatson.com/en/ insights/2018/02/global-pension-assets-study-2018. 